\begin{tabular}{|c|c|c|}
\hline$s t$ & $\begin{array}{l}\text { CARADDE: Jurnal Pengabdian Kepada Masyarakat } \\
\text { https://journal.ilininstitute.com/index.php/caradde } \\
\text { Volume 1 | Nomor 2 | Februari | 2019 } \\
\text { e-ISSN: } 2621-7910 \text { dan p-ISSN: } 2621-7961 \\
\text { DOI: } \text { https://doi.org/10.31960/caradde.v1i2.78 }\end{array}$ & $\begin{array}{l}\text { Iin } \\
\text { CARADDE }\end{array}$ \\
\hline
\end{tabular}

\title{
Pembangunan Media Pembelajaran Berbasis E-Learning Di SMA NU Ma'Arif Jatinegara Tegal
}

\author{
Oman Somantri $^{1}$, Dyah Apriliani ${ }^{2}$, Arif Wirawan Muhamad ${ }^{3}$, M. Nishom ${ }^{4}$
}

\author{
Keywords: \\ e-learning; \\ Media Pembelajaran; \\ Guru;

\section{Corespondensi Author} \\ Program Studi Teknik Informatika, \\ Politeknik Harapan Bersama Tegal \\ Jln. Mataram No.09 Pesurungan Lor \\ Kota Tegal \\ Email: oman_mantri@yahoo.com
}

\section{History Artikel}

Received: Januari-2019;

Reviewed: Januari-2019

Accepted: Januari-2019

Published: Februari-2019
Abstrak. Internet learning sebagai sebuah proses pembelajaran berbasis elektronik yang digunakan sebagai media pembelajaran diberikan untuk para guru dan sekolah di SMA NU Ma'Arif Jatinegara Kota Tegal, melalui kegiatan pelatihan dilakukan sebagai upaya dalam meningkatkan keterampilan dan pengetahuan guru dalam memahami dan membangun e-learning. Metode kegiatan yang digunakan adalah model pembelajaran partisipatif, sehingga diaharapkan dapat memberikan kebebasan kepada para peserta pelatihan untuk lebih memahami materi yang disampaikan. Media yang digunakan untuk membuat $e$ learning menggunakan Edmodo sebagai tools. Berdasarkan hasil evaluasi terhadap kegiatan pelatihan tersebut memperlihatkan $80 \%$ peserta pelatihan sudah mampu membuat media pembelajaran e-learning dengan baik.

\section{PENDAHULUAN}

Pengembangan sebuah model pembelajaran yang sesuai dengan tunttuan perkembangan teknologi saat ini menjadi sebuah kewajiban yang harus dilakukan oleh setiap pendidik di Indonesia. Saat ini teknologi informasi sangat berperan penting dalam segala bidang, termasuk dalam pendidikan. Media pembelajaran yang tepat untuk digunakan saat ini tentunya menjadi pilihan yang harus dilakukan, berpatokan kepada teknologi informasi sebuah media pembelajaran dapat dibuat sesuai dengan tingkatan peserta didik.

Media pembelajaran berbasis teknologi atau dalam hal ini disebut juga dengan e-learning merupakan sebuah penerapan teknologi yang digunakan oleh
Guru atau pendidik yang sesuai saat ini. Elearning merupakan sebuah implementasi gabungan dari antara media internet dengan model pembelajaran sesuai dengan kasus yang dihadapi.

Sekolah SMA Ma'Arif NU Jatinegara merupakan salah satu institusi pendidikan yang letaknya berada di daerah pinggiran Kabupaten Tegal Jawa Tengah. Saat ini sekolah tersebut mempunyai jumlah pengajar Guru sebanyak 17 guru dan mempunyai jumlah siswa aktif sebanyak 386 orang. Saat ini SMA NU Ma'Arif jatinegara menggunakan pola pembelajaran dengan kurikulum KTSP. Berdasarkan data yang ada terkait dengan jumlah pengajar yang cukup banyak sudah tentu perlu adanya sebuah pembinaan yang berkelanjutan khususnya dari sisi kualitas dan perlu adanya peningktan 
proses pembelajaran.

Saat ini SMA Ma'arif NU Jatinegara memiliki insfrastruktur teknologi informasi yang sudah cukup baik, ini terbukti dari beberapa ruang kelas yang ada sudah menggunakan LCD proyektor, adanya laboratorium komputer, laboratorium bahasa dan perpustakaan. Saat ini dalam proses pembelajaran di sekolah tersebut beberapa guru sudah menggunakan laptop sebagai alat bantu dalam proses pembelajaran. Selain kelebihan yang dimiliki oleh sekolah, terdapat kekurangan yaitu pada kegiatan belajar mengajar yang dilaksanakan di SMA NU Ma'Arif Jatinegara masih hanya bersifat menggunakan metode tatap muka di kelas. Terkait dengan keadaan tersebut, apabila hanya mengandalakan metode tersebut maka akan menimbulkan beberapa kendala seperti diantaranya ketergantungan terhadap kehadiran guru dan pelaksanaan pembelajaran tergantung pada sebuah ruangan kelas yang tentunya akan berpengaruh terhadap kurang efisiennya sarana dan prasarana pembelajaran. Permasalahan yang dihadapi saat ini berbanding lurus dengan insfrastruktur teknologi informasi yang dimiliki oleh SMA Ma'Arif NU Jatinegara yaitu belum mempunyai infrastruktur yang lengkap sehingga sarana prasarana ini yang menjadi kendala.

Dalam sebuah proses pembelajaran dikenal dengan e-learning, model ini merupakan sebuah proses pembelajaran yang berbasis elektronik dengan memanfaatkan media jaringan komputer yaitu internet (Benta, Bologa, \& Dzitac, 2014). Saat ini elearning terdiri dari dua media utama dalama internet, yaitu menggunakan media web dan dalam perkembangannya sekarang sudah mulai menggunakan mobile sebagai medianya (Holotescu \& Grosseck, 2011). E-learning saat ini dikembangkan dengan tujuan untuk memudahkan proses pembelajaran sehingga proses pembelajaran dapat dilakukan dimana saja tanpa mengenal tempat dan waktu serta dapat lebih efektif dan efesien. Model pembelajaran e-learning merupakan konsep bagian yang tidak bisa dilepaskan dari kemampuan pedadogik seorang guru atau pengajar. Terdapat beberapa model e-learning yang sering digunakan dalam proses pembelajaran seperti Edmodo
(Balasubramanian, Jaykumar, \& Fukey, 2014), moodle (Carranza, Márquez, Rodríguez, \& León, 2014; Paragină, Paragină, Jipa, Savu, \& Dumitrescu, 2011; Tǎnase-Robescu, 2011), microblogging (Grosseck \& Holotescu, 2011) dan lainnya.

Implementasi dan penerapan $e$ learning sudah dilakukan oleh banyak peneliti untuk pengembangannya (Amandu, Muliira, \& Fronda, 2013) dan oleh tim pelaksana pengabdian untuk diimplementasikan baik itu di sekolah seperti yang dilakukan oleh (Somantri, Abidin, Wibowo, \& Wiyono, 2017) maupun tempat-tempat yang membutuhkan seperti lembaga-lembaga pendidikan. Pengembangan e-learning telah dilakukan oleh beberapa peneliti sehingga penggunaannya lebih baik dan lebih efisien untuk digunakan baik itu dari platform yang digunakan maupun dari segi keamanannnya (Costinela-Luminiţa \& Nicoleta-Magdalena, 2012). Penerapan e-learning diterapkan kepada para guru sekolah tingkatan SMK dalam bentuk multimedia dan tutorial, selain itu guru-guru SMA menggunakan e-learning sebagai upaya dalam peningkatan prestasi siswa dan guru SD menggunakan e-learning sebagai bagian dari upaya peningkatan minat siswa dalam belajar karena lebih interaktif.

Berdasarkan permasalahan yang dihadapi oleh SMA NU Ma'Arif Jatinegara, bertolak pada keadaan tersebut dan sesuai dengan hasil diskusi serta kesepakatan bersama dengan pihak sekolah maka langkahlangkah yang menjadi prioritas uatma dalam mengatasi permasalahan yang ada adalah yaitu diterapkan dan dikembangkannya $e$ learning sebagai salah satu media pembelajaran untuk para guru dan pendidik di SMA NU Jatinegara sehingga adanya sebuah peningkatan pengetahuan dan keterampilan guru dalam pemanfaatan $e$ learning sebagai media pembelajaran yang akan digunakan kepada siswa sebagai upaya peningkatan prestasi dan peningkatan motivasi dalam pembelajaran yang sedang berjalan di SMN NU Ma'arif Jatinegara Tegal.

\section{METODE}

Pengabdian masyarakat dilakukan berdasarkan kebutuhan yang menjadi 

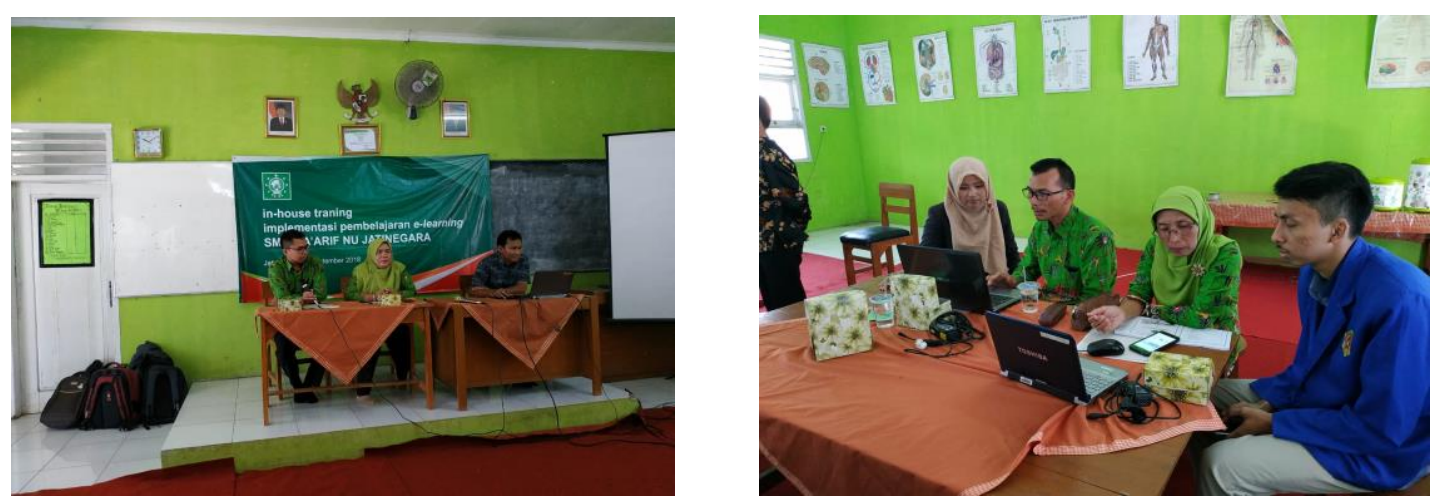

Gambar 1: Pemberian materi pelatihan e-learning oleh Tim PkM

prioritas terhadap permasalahan yang dihadapi. Dalam kegiatan ini terdapat beberapa tahapan yang dilakukan yaitu (1) proses perencanaan, pelaksanaan kegiatan; (2) evaluasi kegiatan dan (3) proses pendampingan. Metode pelatihan yang diterapkan adalah model pendekatan partispatif dimana para peserta pelatihan berperan aktif dalam proses pembelajaran, hal ini dilakukan karena peserta pelatihan terdiri para orang dewasa sehingga lebih sesuai untuk diterapkan.

Tahapan perencanaan dilakukan dengan melakukan observasi ke tempat mitra yang sudah ditentukan. Observasi dilakukan dengan tujuan untuk mendapatkan informasi terkait dengan permasalahan yang dihadapi oleh mitra, dalam hal ini adalah SMA NU Ma'Arif Jatinegara Tegal. Permasalahanpemasalahan yang didapatkan kemudian didiskusikan dengan mitra untuk mendapatkan skala prioritas dalam penanganan permasalahan yang didapatkan. Prioritas solusi berdasarkan kesepakatan adalah dilakukannya pelatihan bagi Guru di tempat mitra mengenai cara pembuatan media pembelajaran e-learning sehingga Guru dapat mengimplementasikannya dalam proses pembelajaran.

Pelaksanaan kegiatan dilakukan sesuai dengan jadwal yang telah ditentukan bersama antar tim dengan mitra. Metode pembelajaran dilakukan dengan model learning by doing, dimana peserta pelatihan akan praktek ketika penjelasan sudah diberikan sehingga peserta pelatihan dapat langsung mengimplementasikan instruksi yang diberikan. Metode pemberian materi dilakukan dengan metode ceramah, diskusi, dan praktek. Pada pelaksanaan kegiatan materi yang disampaikan adalah terdiri dari pengenalan mengenai konsep e-learning dan pembuatan e-learning dengan menggunakan Edmodo. Edmodo merupakan sebuah aplikasi berbasis web yang menyerupai media sosial yang digunakan untuk media pembelajaran jarak jauh antara pengajaran dan siswa yang dapat digunakan dengan mudah dan menggunakan koneksi internet sebagai media komunikasinya (Balasubramanian et al., 2014; Putranti, 2013). Selain itu selain Edmodo terdapat salah satu media yang dapat digunakan yaitu moodle (Carranza et al., 2014), akan tetapi dalam kegiatan ini media tersebut tidak diberikan. Jumlah peserta yang mengikuti kegiatan pelatihan adalah berjumlah 23 orang Guru yang berasal dari SMA NU Ma'Arif Jatinegara Tegal.

Untuk melihat sejauhmana hasil dari pelatihan, maka evaluasi dilakukan dengan cara memberikan tugas kepada peserta pelatihan untuk dapat membuat e-learning sesuai dengan mata pelajaran yang diampunya sehingga dapat langsung digunakan sebagai media pembelajaran kepada peserta didik. Evaluasi ini dilakukan sebagai upaya untuk mengukur tingkat kemampuan peserta pelatihan dalam memahami materi yang sudah disampaikan.

Tahapan terkahir dari kegiatan ini adalah dilakukannya pendampingan terhadap peserta pelatihan yang sudah membuat $e$ learning sesuai dengan mata pelajaran yang diampunya. Pendampingan dilakukan setelah kegiatan pelatihan selesai, dalam hal ini tim PKM (Pengabdian Kepada Masyarakat) melakukan pendampingan sebagai tempat konsultasi bagi para peserta pelatihan apabila terdapat kendala-kendala selama 
mengimplementasikan e-learning tersebut. Pendampingan dilakukan sampai dengan waktu yang tidak ditentukan, selama peserta yang sudah mengikuti pelatihan tersebut merasa sudah terampil dan yakin serta siap mengimplementasikan media pembelajaran $e$ learning tersebut.

\section{HASIL DAN PEMBAHASAN}

Kegiatan PKM dilakukan sebagai upaya untuk meningkatkan pemahaman dan keterampilan guru dalam membuat e-learning. Pelaksanaan kegiatan pelatihan dilaksanakan pada tanggal 25 September 2018 bertempat di kampus SMA NU Ma'Arif Jatinegara Tegal.

\section{Peningkatan Pengetahuan Peserta Pelatihan}

Berdasarkan tujuan yang ingin dicapai pada pelatihan ini adalah meningkatnya pengetahuan peserta mengenai konsep $e$ learning dan penerapannya pada proses pembelajaran yang dilakukan di kelas oleh guru. Pada proses ini peserta pelatihan diberikan pengetahuan yang didalamnya membahas terkait dengan segala yang terkait dengan e-learning mulai dari perkembangan, teknologi, penerapan, kelebihan dan implementasinya dalam proses belajarmengajar dalam upaya peningkatan proses pembelajaran yang dilakukan di sekolah.

Pemberian materi pelatihan ditekankan pada bagaimana upaya guru dalam mengimplementasikan model e-learning sebagai bagian dari salah satu media pembelajaran yang dapat diterapkan sehingga dalam hal ini guru harus bisa memahami konsep, dan teknik keterampilan dalam membuatnya. Sebagai contoh salah satu akun yang dibuat pada pelatihan tersebut adalah seperti pada Gambar 2.

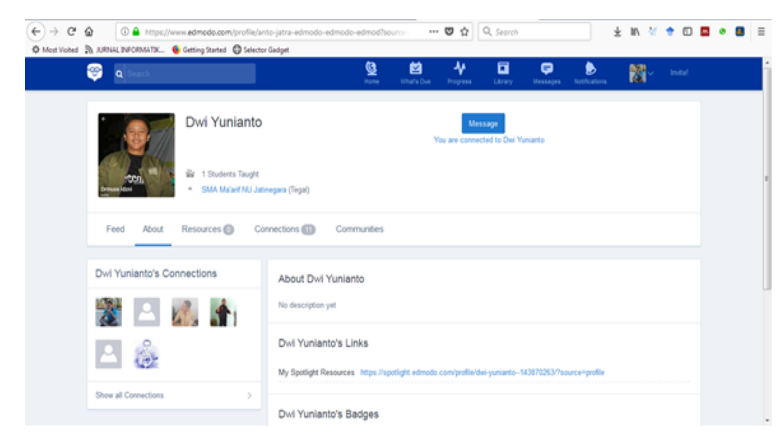

Gambar 2: Contoh account Edmodo salah satu peserta pelatihan

\section{Peningkatan Keterampilan Peserta Pelatihan}

Hasil pelatihan yng dilakukan berdasarkan praktek terhadap penggunaan internet learning dihasilkan beberapa account baru EDMODO yang dibuat oleh para peserta kegiatan sehingga setelah kegiatan selesai dapat diimplementasikan langsung kepada para peserta didiknya di sekolah. Elearning dengan menggunakan Edmodo mempunyai kelebihan selain dapat mudah digunakan dan mempunyai tampilan yang tidak begitu rumit, tetapi apabila dilihat apikasi ini mempunyai fasilitas yang lumayan cukup banyak sebagai media pembelajaran. Peningkatan keterampilan dan pengethuan guru dalam membuat e-learning menjadi fokus pada pelatihan yang dilaksanakan. Kegiatan PKM menghasilkan beberapa akun Edmodo yang sudah dibuat oleh para peserta pelatihan, seperti ditunjukan pada Tabel 1 .

\section{Evaluasi pelatihan}

Pemberian pengetahuan mengenai teknologi e-learning dan pelatihan mengenai keterampilan membuat e-learning diberikan kepada seluruh peserta kegiatan. Untuk mendapatkan sebuah gambaran bahwa tingkat ketercapaian target kegiatan sudah didapatkan. Pada proses ini sebagai evaluasi dilakukan metode penugasan sebagai tolak ukur keberhasilan, tugas yang diberikan adalah berupa pembuatan e-learning sesuai dengan mata pelajaran dari para peserta pelatihan. Berdasarkan hasil evaluasi, dari sebanyak 25 orang jumlah peserta kegiatan ternyata 20 orang bisa membuatnya dengan presentasi keberhasilan adalah $80 \%$ berhasil seperti diperlihatkan pada Grafik 1.

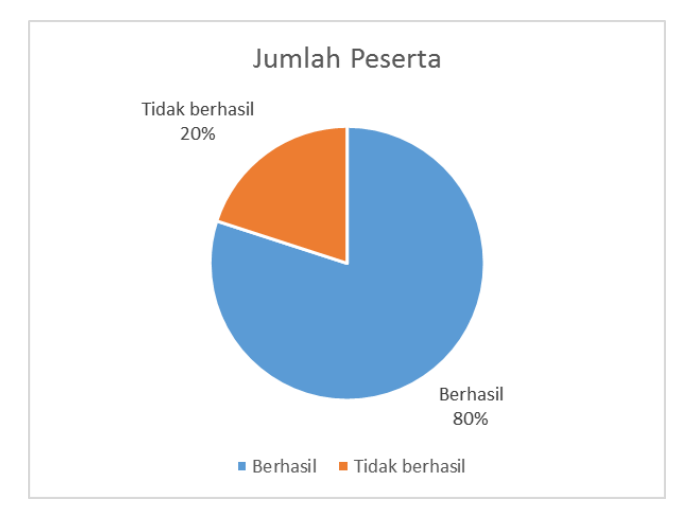

Grafik 1: Presentasi keberhasilan peserta dalam membuat e-learning 
Somantri, Apriliani, Muhamad, Nishom. Pembangunan Media Pembelajaran

Tabel 1: Account e-learning Edmodo yang dihasilkan dari peserta pelatihan

\begin{tabular}{|c|c|c|}
\hline & Nama Guru & Username Edmodo \\
\hline 1 & Dwi Yunianto & $\begin{array}{l}\text { https://www.edmodo.com/profile/anto-jatra-edmodo-edmodo- } \\
\text { edmod }\end{array}$ \\
\hline 2 & Muhamad Sofyudin & $\begin{array}{l}\text { https://www.edmodo.com/profile/edmodo-teacher-97576- } \\
\text { 645f4c2bd }\end{array}$ \\
\hline 3 & Muhammad Asyik & $\begin{array}{l}\text { https://www.edmodo.com/profile/edmodo-teacher-7887e- } \\
\text { c7bbe91d8 }\end{array}$ \\
\hline 4 & Akhmad Rojikin & $\begin{array}{l}\text { https://www.edmodo.com/profile/edmodo-teacher-73359- } \\
\text { 499c2568e }\end{array}$ \\
\hline 5 & Yani wibowo & $\begin{array}{l}\text { https://www.edmodo.com/profile/edmodo-teacher-e2cdb- } \\
\text { e2960bcf9 }\end{array}$ \\
\hline 6 & amirin soleh & $\begin{array}{l}\text { https://www.edmodo.com/profile/edmodo-teacher-b916b- } \\
\text { 0c4fd9a41 }\end{array}$ \\
\hline 7 & Arif Hakim & $\begin{array}{l}\text { https://www.edmodo.com/profile/edmodo-teacher-a23f8- } \\
\text { 1740e9b8a }\end{array}$ \\
\hline 8 & Inamul Auva & https://www.edmodo.com/profile/inamul-auva-edmodo-edmodo \\
\hline 9 & icha Nur Faticha & $\begin{array}{l}\text { https://www.edmodo.com/profile/edmodo-teacher-1103d- } \\
45 \mathrm{c} 2 \mathrm{db} 3 \mathrm{~b} 4\end{array}$ \\
\hline 10 & Laelatul Munawaroh & $\begin{array}{l}\text { https://www.edmodo.com/profile/edmodo-teacher-8d4bd- } \\
5897 \mathrm{c} 20 \mathrm{ca}\end{array}$ \\
\hline 11 & Puji Astuti & $\begin{array}{l}\text { https://www.edmodo.com/profile/edmodo-teacher-e33f6- } \\
\text { fc4a981e2 }\end{array}$ \\
\hline 12 & Suci Triana & $\begin{array}{l}\text { https://www.edmodo.com/profile/edmodo-teacher-b6a8a- } \\
\text { e2d4d992f }\end{array}$ \\
\hline 13 & Ismatul Afwah & $\begin{array}{l}\text { https://www.edmodo.com/profile/edmodo-teacher-7cdc9- } \\
\text { 9503d8bf1 }\end{array}$ \\
\hline 14 & Nurlina Rahmawati & $\begin{array}{l}\text { https://www.edmodo.com/profile/nurlina-rahmawati-ed- } \\
\text { 6576a1a18 }\end{array}$ \\
\hline 15 & Mimik Supriyatin & https://www.edmodo.com/profile/mimikmuhar \\
\hline 16 & Vika Farha Awalia & https://www.edmodo.com/profile/vikafarhaa \\
\hline 17 & Mukhsin & $\begin{array}{l}\text { https://www.edmodo.com/profile/edmodo-teacher-8cc08- } \\
\text { 5a0630d8a }\end{array}$ \\
\hline 18 & Nina Fahrina & $\begin{array}{l}\text { https://www.edmodo.com/profile/edmodo-teacher-4c9ef- } \\
\text { 0b3ff945a }\end{array}$ \\
\hline 19 & Sigit budi kurniawan & $\begin{array}{l}\text { https://www.edmodo.com/profile/sigit-budi-kurniawan- } \\
\text { bc202c656 }\end{array}$ \\
\hline 20 & Surip Faqih & $\begin{array}{l}\text { https://www.edmodo.com/profile/surip-faqih-edmodo-e- } \\
\text { 657d899d5 }\end{array}$ \\
\hline
\end{tabular}

\section{SIMPULAN DAN SARAN}

Media pembelajaran e-learning mempunyai pengaruh besar terhadap proses belajar mengajar yang dilakukan oleh guru dan siswa dikelas. Media pembelajaran elearning merupakan salah satu alternatif yang dapat digunakan oleh peserta pelatihan yaitu guru SMA NU Ma'Arif Jatinegara Tegal. Keterampilan dalam membuat media pembelajaran berbasis teknologi informasi bukan hanya saja menggunakan satu teknologi Edmodo saja, akan tetapi masih banyak tools lain yang dapat digunakan sehingga guru harus tetap meningkatkan keterampilan dalam membuat media tersebut sehingga dapat menggunakan media pembelajaran alternatif lain sebagai inovasi dalam proses belajar mengajar. Proses pendampingan yang terus-menerus terhadap peserta pelatihan yang telah selesai disarankan untuk tetap dilakukan sebagai upaya monitoring dalam pencapaian kegiatan yang telah dilakukan.

\section{DAFTAR RUJUKAN}

Amandu, G. M., Muliira, J. K., \& Fronda, D. C. (2013). Using Moodle E-learning 
Platform to Foster Student Self-directed Learning: Experiences with Utilization of the Software in Undergraduate Nursing Courses in a Middle Eastern University. Procedia - Social and Behavioral Sciences, 93, 677-683. https://doi.org/10.1016/j.sbspro.2013.0 9.260

Balasubramanian, K., Jaykumar, V., \& Fukey, L. N. (2014). A Study on "Student Preference towards the Use of Edmodo as a Learning Platform to Create Responsible Learning Environment." Procedia - Social and Behavioral Sciences, 144, 416-422. https://doi.org/10.1016/j.sbspro.2014.0 7.311

Benta, D., Bologa, G., \& Dzitac, I. (2014). Elearning platforms in higher education. Case study. Procedia Computer Science, 31, 1170-1176.

https://doi.org/10.1016/j.procs.2014.05 .373

Carranza, R. R., Márquez, A. A., Rodríguez, F. M. L., \& León, O. G. (2014). Modeling in E-learning System. AASRI Procedia, 8(Secs), 57-62. https://doi.org/10.1016/j.aasri.2014.08. 010

Costinela-Luminiţa, C. (Defta), \& NicoletaMagdalena, C. (Iacob). (2012). Elearning Security Vulnerabilities. Procedia - Social and Behavioral Sciences, 46, 22972301.

https://doi.org/10.1016/j.sbspro.2012.0 5.474

Grosseck, G., \& Holotescu, C. (2011). Teacher education in 140 characters Microblogging implications for continuous education, training, learning and personal development. Procedia Social and Behavioral Sciences, 11, 160164.

https://doi.org/10.1016/j.sbspro.2011.0 1.053

Holotescu, C., \& Grosseck, G. (2011). Mobile learning through microblogging. Procedia - Social and Behavioral Sciences, 15, 4-8. https://doi.org/10.1016/j.sbspro.2011.0 3.039

Paragină, S., Paragină, F., Jipa, A., Savu, T., \& Dumitrescu, A. (2011). The Moodle course management system and its elearners' needs. Procedia - Social and Behavioral Sciences, 15, 1226-1230. https://doi.org/10.1016/j.sbspro.2011.0 3.267

Putranti, N. (2013). Cara Membuat Media Pembelajaran Online Menggunakan Edmodo. Jurnal Pendidikan Informatika Dan Sains, 2(2), 139-147.

Somantri, O., Abidin, T., Wibowo, D. S., \& Wiyono, S. (2017). Peningkatan Kemampuan Guru Dalam Membuat E Learning Sebagai Media Pembelajaran Berbasis Teknologi Informasi Di Sma Negeri 1 Subah, 23(September).

Tănase-Robescu， D. (2011). Deploying moodle capabilities to showcase interactive content and language learning in the engineering students' foreign language training. Procedia Social and Behavioral Sciences, 15, 11531157. https://doi.org/10.1016/j.sbspro.2011.0 3.254 